\title{
THE RELEVANCE OF RONALD DWORKIN'S THEORY FOR CREATING AGRARIAN JUSTICE IN INDONESIA
}

\author{
Muh. Afif Mahfud ${ }^{1}$ \\ ${ }^{1}$ Ph.D Student, Faculty of Law, Universitas Diponegoro \\ Email: afifmahfud4@gmail.com
}

\begin{tabular}{l}
\hline Article Information \\
\hline Submitted : August 27, 2019 \\
Accepted : December 30, 2019 \\
Keywords : \\
Relevance, Ronald Dworkin's \\
Theory, Agrarian Justice \\
\end{tabular}

Abstract
Law enforcement related to Agraria is unjustly marked by the
discrepancy of natural resources ownership and many agrarian
conflicts. This is normative research, use conceptual approach and
secondary data. Then, data collected is analyzed qualitatively.
Based on research, moral reading stated by Dworkin is very
relevant to be implemented to create agrarian justice in Indonesia
because of its endorse rule to be interpreted according to the
justice principle. Dworkin's theory of justice is very relevant in
creating justice in Indonesia because of : (1) emphasize the
importance of public participation and individual understanding
in constructing justice; (2) acknowledgment of public diversity;
and (3) giving attention to disadvantaged people.

\section{Introduction}

One of the goals of the Indonesian state is to advance public welfare. To realize these objectives the natural resources should be controlled by the state as a public organization to improve the welfare of the people who called the right of state's control. The word "rights" indicates the authority possessed by the state to regulate and distribute the benefits of natural resources to the community. (Julius Sembiring, 2016: 119). This is due to the relationship between the state, citizens of natural resources are the main thing that is not only the basis of the establishment of the Indonesian state but also determines the existence of this country in the future and affects the welfare of society. Therefore, the exercise of the state's right to control must be carried out based on social justice. (Nurma, 2016). Social justice has two dimensions, namely the material dimension, where the condition in which all people get benefits and their needs are met for natural resources. Besides, there is also an immaterial dimension which is the condition where the people's preferences are fulfilled. The combination of material and the immaterial dimension will create people's welfare. Based on reality, the welfare of the community in the context of the management or distribution of natural resources has not yet been created (Suradi, 2007: 5). One of the causes is agrarian injustice which is evident from the polarization of ownership of natural resources in one person or business entity, the taking over of community rights to natural resources, the role and will of the community in the management of natural resources including land. These various conditions cause an imbalance in the mastery of natural resource utilization in the community. Based on research by the Bogor Agricultural Research and Development Agency, the number of farmers who do not own land continues to increase from year to year both in Java and

1 Doctoral Student, Faculty of Law, Universitas Diponegoro. correspondence email: afifmahfud4@gmail.com 
outside Java. (Bambang Winarso, 2017: 143). An ironic thing also appears in the results of the Central Statistics Agency research in 2007 as quoted by Dianto Bachriadi and Gunawan Wiradi that the number of farmers who owned land less than 0.1 hectares in 1973 was $3.4 \%$ of the total population while in 2003 that number is $10.9 \%$. This means that more and more people have less than 0.1 hectares of land. (Dianto Bachriadi, 2011: $44)$. In 2007, $0.2 \%$ of Indonesia's population controlled 56 percent of assets in Indonesia, $87 \%$ of which was in the form of land (Joyo Winoto, 2007: 2). This was also confirmed in the world bank executive summary in 2015 which stated that only a small number of Indonesians had financial and physical access such as land in Indonesia (Vivi Alatas, 2016: 50). The lack of control of natural resources, especially land, causes people to live in poverty and there is an imbalance of wealth in Indonesia. Even though land rights are a basic right to be able to access food, housing, and development.

This condition occurs because there is sectoral management of natural resources, so there is cohesiveness in its management which results in the potential exploitation of natural resources and injustice for people whose lives depend on natural resources (Muhammad Ilham Arisaputra, 2016: 84), overlapping laws and regulations. overlap and do not refer to the purpose of the right to control state for the greatest prosperity of the people and was followed by a developmental paradigm or development that negates the rights of society. One important thing that causes the emergence of injustice in natural resource management is the existence of a law that is not progressive both in the text of the legislation and in its enforcement. The non-progressive regulation related to natural resource management is caused by the regulators adopting liberal and capitalist understandings which are more inclined to spur economic development and growth but at the expense of the people's right to natural resources. The politics of agrarian law is contrary to the goal of the right to control the state, namely the maximum prosperity of the people. On the other hand, law enforcement in Indonesia is also fixated on the positivist paradigm which is evident from the black and white reading of the text of the legislation and tends to be the trumpet of the legislation and is not based on the value of justice. The legislation was reading in black and white has been disabled since birth because it does not correspond to the values of justice. As a result, the control of resources in the community is getting lame and the potential increase in poverty more open. Under such conditions, changes are needed in the making and law enforcement in the field of natural resources. Law enforcers must read or interpret the laws and regulations based on the value of justice so that public welfare can be created. Also, the distribution of natural resources must provide facilities for disadvantaged people. The reading of the text or the interpretation of legislation based on fairness and concern for its ease disadvantaged communities put forward by Ronald Dworkin. For this reason, the author will analyze the relevance of using Ronald Dworkin's theory to create agrarian justice in Indonesia. Based on the above background, two problems can be formulated, namely: (1) How is the relevance of the use of moral reading proposed by Dworkin in creating agrarian justice in Indonesia?. (2) How is the relevance of Dworkin's theory of justice for creating agrarian justice in Indonesia? 


\section{Research Methods}

This research is normative legal research related to the relevance of the theory put forward by Ronald Dworkin to create agrarian justice in Indonesia. This paper uses a conceptual approach that aims to understand the views and doctrines related to the object of analysis. This research is research literature or literature that uses secondary data. The data obtained will then be analyzed qualitatively.

\section{Discussion}

\section{The Relevance of Using Ronald Dworkin's Moral Reading to Create Agrarian Justice in Indonesia}

Discussion on moral reading will begin with a discussion on the importance of interpretation in law because moral reading itself is a way to interpret the law based on morality. Therefore, the interpretation of the law is an important thing even central in a law enforcement process. (Jerzy Wroblewski, 1969: 3) Satjipto Rahardjo stated that the law cannot be enforced without interpretation because it is through interpretation that legislation can be applied fairly and grounded. (Satjipto Rahardjo, 2009: 125) This interpretation will determine the actions and decisions of the law enforcement because the action is an embodiment of human interpretation and understanding. In this case, if law enforcement officials only use grammatical interpretation, the law enforcer will act following the text of the legislation. On the other hand, law enforcement officials can also do teleological interpretations or interpretations that refer to the purpose of making a statutory regulation.

Interpretation of a text of legislation will always be done in the process of law enforcement. This is due to a text of legislation that will never probably be able to handle all the problems that arise in the future. Therefore, law enforcement must always be interpreting legislation to solve existing problems. According to R.T. Manko, there are three reasons why interpretation must always be made of a text of the legislation, namely: (Manko, 2016: 119). First, the legal language is open textured or opens up space for interpretation. Based on this nature, the interpretation of a legal text is something that cannot be avoided. Second, a text of the law sometimes does not clearly state its purpose. Therefore, it is important to interpret the laws and regulations so that they are under the objectives to be achieved. Third, legislation although made but can not cover all events that will occur. This is even more relevant when related to current conditions where law enforcement is also influenced by the rapid development of information. In such conditions, law enforcers have to interpret the laws and regulations so that they remain relevant to the case at hand. The description indicates that the interpretation is important in law enforcement and interpretation of a text is the law that will affect the attitudes and decisions of law enforcement. Understanding the importance of the role of interpretation in law enforcement, there are a variety of concepts and theories advanced by experts regarding the interpretation of legislation including Ronald Dworkin. According to him, the legislation must be interpreted morally or morally reading.

Interpretation or moral reading cannot be separated from the legal analysis by Dworkin who is always associated with morals. Departing from this, the writer is 
important to express the meaning of the moral both etymologically and Dworkin >s interpretation of morality. The term moral, morality comes from the Latin words «mos» (singular), "mores" (plural) and moralist adjectives. The plural form of mores means habit, behavior, and decency. The moralist adjective means immorality. (A Gunawan, 1990: 93). In Dworkin`s view, morality is treating others properly. (Ronald Dworkin, 2011: 13). Law is a branch of political morality. In this case, a text of the legislation is not only seen textually but in it there is morality. (Ronald Dworkin, 2005: 78). Dworkin places law as political morality. (Ronald Dworkin, 1986: 97). This is the same as Peter Caness opinion that law is part of morality and the law can ensure the upholding of morality because it has binding power (Peter Cane, 2002: 2). In addition to placing law as part of morality, Dworkin also places justice as part of political morality and even justice is the best political morality.

The statement is also in line with Wojciech Sadurski>s opinion that justice is very important even the most important values in a society. (Wojciech, 1985: 12) This makes justice a central position in interpreting the law. In his view, the interpretation of the law is the activity of interpreting or interpreting that is based on moral values. (Ronald Dworkin, 2005: 7) This means legislation must be interpreted morally or morally reading. Dworkin states that to create justice should not only hold on the substance of the legislation but more than that it must also adhere to the principles in the life of society the main principle is justice. These principles can be found in the formulation of the constitution including the principle of justice itself. A law must be assessed for its suitability with justice and even the interpretation of the text of the law must also be based on the value of justice. (Ronald Dworkin, 2013: 121).

Interpretation of the moral legislation namely justice is very important to do now by judges in agrarian law given the many cases in the agrarian field that have been sacrificing the small community. Based on 2008 research, there were 100 agrarian disputes involving indigenous and tribal peoples in the courts in the Province of West Sumatra and none of these cases won any indigenous peoples. Besides, the interpretation of the law based on the values of justice by judges is also increasingly important to be carried out today considering the natural resource law politics in Indonesia at this time is liberal capitalistic which focuses on the use of natural resources on a large scale for capital owners and foreign investors and forgetting even sacrificing the community around the location of the utilization of these natural resources. This not only causes injustice but also poverty and environmental damage. (Ahmad Nashih Lutfi, 2012: 143). This is consistent with Emilianus SeseTobo's research which states that one of the causes of poverty in Flores is the imbalance of agrarian structures. (Tobo Emilianus, 2016: 181).

Government, through a liberal capitalistic policy, has seen natural resources as an economic commodity even though the relationship created between the community and natural resources is a socio-cultural relationship in which there are various symbols and local wisdom. (Husen Alting, 2013: 268). Faced with these conditions, the government tends to choose to prioritize development and ignore socio-cultural relations between people and natural resources. In this case, the judges must uphold justice in the natural resource field by making progressive decisions and not just 
sticking to the laws and regulations, and even judges must be critical of regulations that rob the rights of indigenous and tribal peoples such as Law No. 41 of 1999 concerning Forestry which has usurped the rights of indigenous and tribal peoples over their forests by categorizing them as state forests. Also, there is a state policy that conducts the nationalization of customary law community land as happened in Deli. (OK Saidin, 2015: 28) In such conditions, the judge must be a milestone to create agrarian justice through the interpretation of legislation morally (moral reading) and prevent the sacrifice of society in the utilization of natural resources through progressive decisions.

The role of judges in creating agrarian justice is now increasingly important given the many agrarian conflicts in Indonesia. Based on the final report of the Agrarian Reform Consortium, in 2010 there were 106 agrarian conflicts in Indonesia, that number increased to 163 agrarian conflicts and even killed 22 farmers or residents in 2011. In the following year, 198 agrarian conflicts with an area of conflict reached 963,411.2 hectares and also involved 141,915 heads of households. From 2004 to 2012 , the number of agrarian conflicts reached 618 agrarian conflicts, the area of land that became the object of conflict reached 2,399,314.49 hectares and involved 731,342 households (Final Report of the 2012 Consortium for Agrarian Reform. "Buried Agrarian Justice for the People through Reforma Agrarian “). The many agrarian conflicts that can become agrarian disputes become a challenge for judges in creating agrarian justice. In dealing with such a large number of cases, judges must not only adhere to the laws and regulations but must achieve the value of justice. It's mean that the judge must read legislation morally or morally reading.

The book Freedom>s Law: The Moral Reading of the American Constitution, it is explained that in reading or interpreting morally the text of the law, two steps must be taken, namely (a). Understand the purpose or purpose of forming the legislation. In this case, the historical approach becomes important in knowing the purpose of the establishment of the law, and (b). Read a text of the legislation based on the law as integrity. The description of law as integrity is not described in the same book by Dworkin but is described in a different book namely Law's Empire. The book states that Law as Integrity denies that statements of law are either backward-looking factual reports of conventionalism or the forward-looking instrumental program of legal pragmatism. It insists that legal claims are interpretive judgments and therefore combine backward and forward-looking elements.

The description indicates that the law as integrity, the law is interpreted by using the incorporation of backward and forward-looking. Backward-looking stated because at this stage wanted to be known about the process of making rules and the substance of these regulations. Backward-looking identical to the first stage of the process of interpretation is the stage of pre interpretive. In this case, the judge who handled the case in the field of agrarian should pay attention to what political and legal objectives adopted in the legislation. This is important because if a rule has caused injustice judge must put it aside for the sake of justice. (Radbruch, 2006: 6).

The second stage is the interpretive ie does the interpretation of the correspondence between the substance of the legislation with the values of justice. 
In this case, compliance with the value of justice must be seen. The value of justice can be measured from two aspects, first, the equitable utilization of resources by the community. Second, the ease to people who are disadvantaged or who have less ability to access natural resources. If a discrepancy is found with the value of justice and is not suitable to be applied in a concrete case, a judge must proceed to the third stage, the post interpretive or reforming stage, namely the stage of forming a new decision in the agrarian field based on the values of justice.

The description above shows that the use of moral reading or reading specific legislation based on morality makes the judge can make a breakthrough in passing the verdict and enforcing the law so that it is following the value of justice. In this case, the judge is no longer just a trumpet of the legislation but can produce a fair decision based on reflection and in-depth assessment of both the background and objectives to the compatibility of the laws and regulations with the value of justice. That is, law enforcement through the interpretation of Ronald Dworkin will create substantive justice, not procedural justice. According to Satjipto Rahardjo, through this moral reading, the judge does not only spell but reaches justice as the deeper meaning of statutory regulation (Satjipto Rahardjo, 2007: 41). In such conditions, the judge is responsible for celebrating the law based on the value of conscientia, namely justice. This is because the judge will give the verdict and sentence in a case.

Reading by Ronald Dworkin makes justice the basis for interpreting legislation and forming decisions. This is consistent with Eskridgess opinion that in interpreting based on justice, several things must be done, first, the interpreter should not only consider the text of the legislation and the history of its making but also the entire law relating to agrarian law. In this case, the interpreter must place the law as something open and not isolated (William N. Eksridge, 1989: 1016). Second, the interpreter must view the legislation as something dynamic, so an interpreter must be able to understand the dynamics in legal politics in the agrarian field and assess its suitability with the values of justice. Third, the interpreter must also be able to understand public awareness about the distribution of natural or agrarian resources fairly. This is following the background of the formation of national agrarian law, namely creating agrarian law that is following the legal awareness of the community. Therefore, judges as interpreters must be able to capture people's understanding of agrarian justice and place community rights over natural resources as human rights (Yance Arizona, 2010: 51) Community understanding needs to be considered because its understanding is different from national law. According to the customary law community, the law is magical, cash, concrete and flexible in the communalistic atmosphere of the community which is different from the formal-legalistic state law which relies on legal regulations and formal and written evidence.

\section{The Relevance of Using Ronald Dworkin>s Theory of Justice for Creating Agrarian Justice in Indonesia}

Stated that justice is a branch of morality and even the best political morality. This is also consistent with the statements of various legal experts including Bur Rasuanto who stated that justice is the highest primary value or the primacy of justice (Rasuanto, 2005: 6). Jimly Ashshiddiqie called justice the highest norm in 
state life. (Jimly Asshiddiqie, 2018: 147) The placing of justice as the highest value is due to justice related to community welfare or the equitable distribution of agrarian resources. Realizing justice in the agrarian sector is now a big problem for this nation. This is because agrarian inequality still occurs in Indonesia, both inequality in land ownership and other natural resources, the existence of unfair laws and regulations because it eliminates community access to enjoy natural resources and the absence of community rights to actively participate in determining public policies. Based on these conditions, it is fitting to make a fair policy in the field of natural resources called agrarian justice. Agrarian justice can be defined as a condition where the structure of agrarian resource tenure does not show the imbalance of agrarian resource tenure and provides a space for community participation in natural resource management (Fatimah, 2015: 119).

Order to create fair policies in the field of natural resources many experts put forward various theories of justice including Ronald Dworkin and most recently Peter A. Corning. For Corning, justice involves three things: first, goods and services must be distributed to everyone based on their basic needs. Second, the excess or surplus of resources after each person's basic needs are met must be distributed based on the merit or effort of that person. Third, all people must contribute to the efforts to meet mutual needs by their abilities. (Peter Corning, 2012: 200). Peter A Corning>s theory is in harmony with Ronald Dworkinss theory that the equitable distribution of resources must meet everyoness basic needs, but there are differences between the two, namely Dworkin in his theory of justice also discusses personal preference, which considers understanding and individual desires and taking into account aspects of contextuality. The existence of this concept also distinguishes Dworkin s theory of justice from the theory of justice proposed by John Rawls, although there is also a point of similarity, for disadvantaged people must be given easy access to resources. At this point, Dworkin rejects equality of welfare which does not take into account personal preferences and chooses equality of resources as the basis for building a theory of justice. Dworkin >s theory of justice is what will become the authorss foundation in the study of the creation of agrarian justice in Indonesia. According to the author, Ronald Dworkinss ideas about fairness in the distribution of resources can be divided into three understanding which is described below.

\section{The Importance of Public Participation and Individual Understanding in Constructing Justice}

Dworkin's main ideas is that the creation of a just law must be sensitive to aspects of culture, history and individual actions which then become social practices in society. In this context, to know the social practice, it must first know the understanding of the individuals involved. (GunawanSetiardja, 1990: 97) That is, in making legislation must also include the community or individuals involved. This statement is in line with Wojciech Sadurski's opinion that the best way to interpret the moral concept is by knowing what the community means about a moral concept including justice. That is, justice is whatever the public defines as justice. 
Community participation is important because justice in the text of laws and regulations will be created if there is agreement from a variety of different individual understandings. The making of legislation must be implemented holistically where different interpretations or individual understandings result from different values, experiences, and goals put together without knowing the hierarchy and subordination (sharing interpretive concept). This is what Dworkin stated with justice as a constructive interpretation. Dworkin through his description has shown the importance of involving individuals in the process of making laws and regulations.

For Dworkin, the community is a moral member of the political community who has the right to participate in political decision making. Each individual is expected to play a role in maintaining and developing the values, traditions, and culture that they hold. This has two positive effects, first, everyone has the right to have different views in collective decision making. In making these decisions the principle of abstraction is adopted, namely, the parties have the freedom to express their opinions to protect themselves and their own or make corrections to regulations which they deem unfair. Besides, everyone also has the right to identify what he considers to be good things and the ways that can be taken to get a good life. Dworkin ss statement is also in line with Jenifer Trusted >s statement that humans are moral agents who have the freedom to choose their actions. (Jennifer Trusted, 1987: 1). Second, the decision-making process must pay equal attention to all members of the community, especially regarding the distribution of resources that are expected to bring benefits to all parties. Third, the decisionmaking process must provide conditions that encourage the individuals within it to arrive at conclusions on existing problems based on reflective individual judgments. Based on this, each individual is free to make choices based on his desires in relative terms and determine what matters valuable in his life.

Dworkin ss view, justice is sensitive to individual character and cannot be measured based on a quantitative approach but justice can only be generated through joint decision making between community members and related agencies. Then, joint decision-making is also important to know each individual >s assessment. It is important to know and study the understanding of individuals concerned about what is fair or unjust, right or wrong, good or evil, personal expressions or commitments that guide their lives.

Descriptions above, justice can be created if a rule is based on an agreement with the relevant parties which of course in the process there will be a variety of understandings. The relationship between justice and diversity of understanding is described in discussions about the society which are based on the principle of justice. In the community of principle, laws will be created, selected, modified, developed and interpreted in ways that are by the values of justice and respect for diversity within society. The community of principle respects the existence of a morally pluralistic society and the existence of a variety of different understandings which is then compromised to develop regulations that can accommodate such diversity. This means that diversity in understanding is morally valued by Ronald Dworkin. 
Emphasis on the importance of public participation and individual understanding in creating justice becomes very relevant for adoption and application in national agrarian law. (Vel J.A.C, 2010: 46) There are three benefits of public participation, namely (1) accommodating aspirations regarding policies, (2) facilitating public understanding of the substance of the policy to be made and (3) feeling part of the policy. Ironically, there are laws and regulations in Indonesia that exclude public participation such as Article 14 of Law No. 27 of 2007 concerning Management of Coastal Areas and Small Islands which then carried out judicial constitutions in the Constitutional Court of the Republic of Indonesia (Yance Arizona, 2011: 63). In Decision of the Constitutional Court of the Republic of Indonesia Case No. 3 / PUU-VII / 2010 stated that the lack of space for public participation is contrary to the constitution because it is a form of silencing community rights and the absence of public participation will eliminate public rights. Public participation in developing an agrarian policy must be genuine participation and not artificial participation. Original participation is participation that gives space for the community to determine the decision or policy to be made rather than pseudo participation which only places the community as an object that cannot influence the decision or policy to be taken.

\section{Respect for the Diversity of Cultural Community}

States that regulations must pay attention to the complexity inherent in society including cultural aspects (Ronald Dworkin, 2985: 3). This is because a person who is brought up by a different culture will lead to different judgments. The issue of justice is a matter of interpretation so its contextual nature can differ between one place and another and at one time and another time. For Dworkin, respect for cultural diversity becomes important in the society because the culture is not only psychological but also related to ethics. In the book Justice for Hedgehogs, ethics is defined as living life well. Dworkin puts justice as a parameter of ethics. (Ronald Dworkin, 2000: 261) A life that is good and right in its view is very contextual. In a sense, life is considered good depending on the culture of the nation or the culture of a community. In this case, each community has its own ethical life because it has a different culture. To create justice, cultural diversity within the community needs to be accommodated in the formulation of regulations. the statement above is also following Amartya Sen's opinion that justice must not be determined by the authorities because justice should be based on the will of the people and not the result of government speculation (Amartya, 2009: 9). In such a context, the meaning of social justice created will be following the values and understanding of the community. Consequently, complex community thoughts and values must be considered in making decisions so that justice can be realized. Everyone's thoughts and judgments are indispensable because their thoughts and judgments are important in understanding the meaning of justice. That is, the assessment of the meaning of social justice must be based on a diversity of viewpoints. Based on the diversity of understanding of 
the community, in every policy, the government must conduct open discussion and in-depth research on a policy.

In his other work, Taking Right Seriously, stated that it is important to understand the role of a tradition for the community concerned so that later on these laws and regulations can be supported by the local community. The explanation above shows that a statutory regulation must be contextual. This contextuality means that social justice is not just a matter of distribution but is much broader in scope, namely the overall moral dimension in political, economic and other aspects of social organization. Therefore, a statutory regulation should be a reflection of peopless understanding and culture. (Yanis Maladi, 2012: 436). cultural diversity in Dworkin >s view shows that justice is very contextual because it is influenced by space and time. In this case, a just agrarian law must be sensitive to the cultural diversity of Indonesian society or which in Werner Mensky language is culture-specific. Mensky stated that social justice must be following the culture of society and on the other hand the culture of society must also be following the value of justice. Likewise, state law must be based on the value of justice and pay attention to the culture of society. The interaction of these three aspects will create perfect justice. Justice is very important in Indonesia because in Indonesia there are a variety of indigenous and local communities who understand that natural resources are not only economic but also social and cultural. In this case, the understanding of the community must be taken into account in creating a fair policy in the field of natural resources. Lilis Mulyani stated that in making legislation or judges> decisions, judges must carry out the importance of contextual laws or following the economic, social and cultural conditions of the community and will be accepted and can be effective in society and will create perfect justice for the community. Mulyani, 2008: 69)

\section{Equality of Resources: Giving Attention to Less Fortunate Communities}

Stated that justice can be created if there is an agreement with related parties and can respect the cultural diversity of the community. The foregoing has much to say about fair policy-making but it has not been discussed about the meaning of justice itself. Justice, in the end, is the fulfillment of individual rights. According to him, so justice can be created it is important to adhere to the principle of equality of resources. Equality of resources is based on the abstract egalitarian principle, namely, the government is obliged to make people's lives better and show equal attention to the lives of each person. Every person who accepts the abstract principle will place equality as a political ideal and still recognize the diversity of understanding and culture in society. This opinion is very relevant to be applied to disadvantaged communities and customary law communities. In the context of indigenous and tribal peoples, the government must realize that indigenous and tribal peoples have customary rights, namely the authority to manage their territories autonomously.

Dworkin, equality of resources is related to the treatment of humans in meeting the needs of life and the protection of their ownership. This is consistent 
with Thomas Painess opinion that agrarian justice requires the protection of community ownership and equitable distribution of natural resources for all communities (Thomas Paine, 1999: 87). To create justice, it is first necessary to understand that the community has rights that must be respected so that regulations that do not respect the rights of the community should be considered for their existence. Another important part of the theory of justice proposed by Dworkin is the alignment of disadvantaged people. In his view, people have different abilities. Therefore, different policies are needed for it. This is important so that everyone can meet their basic needs and take advantage of existing opportunities. To explain the disadvantaged people mentioned above, writing will refer to the disadvantaged categories of people according to Amartya Sen, namely (1) Personal diversity; society has different characteristics both in terms of age, gender, disability and others that make their needs very diverse for example a disability or a sick person may need more income to do elementary things than a healthy person; (2) Diversity of income levels in society. In this case, the disadvantaged people have a low income; (3) Diversity in social conditions: Social conditions greatly affect access to health and education services; and (4) Differences in patterns of community behavior that also affect peopless welfare.

The differences in the ability of the community concerning elementary matters as above are very important to determine the services that must be provided. In this case, services to these groups should be given facilities. According to Dworkin, the existence of equal or more severe treatment to disadvantaged communities will produce even greater catastrophic injustice. Attention to disadvantaged people is Dworkin's main topic in his book Sovereign Virtue, stating that disadvantaged people need more attention in the distribution of resources. Attention to disadvantaged people is a moral form while the distribution of resources is related to economic aspects. In connection with this, it is stated that the moral foundation is very important for an economy that aims to realize social justice. (Sri Edi Swasono, 2007: 36) This disadvantaged community arises because of the resourced definite and liberty deficit. Resource deficit is the gap between the resources needed and the resources that can be obtained. The liberty deficit is a condition where a person is limited to obtain something because of certain limitations or conditions compared to what he can achieve in an equal distribution.

Overcome these two problems, Dworkin put forward the concept of improvement, namely improvement of people who experience resource deficits and also liberty deficits. In the context of improvement, the government must pay attention to political preferences, namely equal attention to the fate of everyone over their ownership. Thus, every distribution policy carried out by the government must consider the condition of disadvantaged people. The concept of improvement that emphasizes convenience for those who are less fortunate. This is in line with affirmative action. Ashwini Despande defines affirmative action as a program for people who suffer from injustice and inequality. According to Sukirno, there are several principles of affirmative policy, namely: (Sukirno, 2015: 333) First, research before making laws and regulations. In this case, the 
process of forming legislation must be formed through public participation and accommodate the aspirations of the people. Second, the guiding principle that comes from Pancasila. In this case, Pancasila, especially the fifth precepts must be the test stone in making laws and regulations. Third, social justice which is affirmative action is justice that is in favor of disadvantaged communities. Fourth, there is an equal opportunity to access existing facilities.

On the description of Ronald Dworkin above, a fair agrarian policy must provide facilities for disadvantaged people, those who experience liberty deficit and resource deficit in accessing and obtaining protection for their ownership of natural resources. The facility is in the form of permission processing and rights as well as the equitable distribution of natural resources to disadvantaged communities. That is, in the distribution of natural resources, the inequality of ability within the community must be of a minimum minimorum, a situation that provides maximum facilities for disadvantaged people. This means, even though the community and corporation can both be the subject of the right to a natural resource, but in its distribution must prioritize disadvantaged communities (M. Yazis, 2013: 47). Ronald Dworkin>s theory is very relevant in the distribution of natural resources in Indonesia due to the many disadvantaged communities both economically, educationally and other aspects of life.

\section{Conclusion}

In the description above, it can be concluded that: first, the moral reading proposed by Dworkin is very relevant in creating agrarian justice in Indonesia because it encourages the interpretation of the statutory text based on the value of justice. In the agrarian context, it is important to protect the rights of the people amid Indonesia>s agrarian legal politics that is capitalist-liberal in nature which is not only unfair but also causes poverty in society and triggers agrarian conflicts. Second, Ronald Dworkin s theory of justice is also relevant in creating agrarian justice because (1) emphasizes the importance of public participation in constructing justice; (2) respect for the cultural diversity of the community; and (3) pay attention to disadvantaged people.

Author suggest the government to make agrarian policies must open public participation and also pay attention to disadvantaged people. In the process of enforcement, law enforcers, especially judges, must read the text of the legislation morally in the form of implementation of the value of justice.

\section{REFERENCES}

\section{Books:}

A Gunawan Setiardja. (1990). Dialektika Hukum dan Moral: Dalam Pembangunan Masyarakat Indonesia. Yogyakarta : Kanisius.

Ahmad Nashih Luthfi (ed). (2012). Kebijakan, Konflik dan Perjuangan Agraria Indonesia Awal Abad 21 : Hasil Penelitian Sistmatis STPN, 2012. Penerbit : Pusat Penelitian dan Pengabdian Kepada Masyarakat, Sekolah Tinggi Pertanahan Nasional. 
Amartya Sen. (2009). The Idea of Justice. Massachusetts : The Belknap Press of Harvard University Press.

Dianto Bachriadi dan Gunawan Wiradi. (2011). Enam Dekade Ketimpangan Masalah Penguasaan Tanah di Indonesia. Bandung: Agrarian Resource Center (ARC), Bina Desa, Konsorsium Pembaruan Agraria (KPA).

Gunawan Setiardja. (1990). Dialektika Hukum dan Moral : Dalam Pembangunan Masyarakat Indonesia. Yogyakarta : Kanisius.

Jennifer Trusted. (1987). Moral Principles and Social Values. London : Routledge \& Kegan Paul.

Jimly Ashshiddiqie. (2018). Konstitusi Keadilan Sosial : Serial Gagasan Konstitusional Negara Kesejahteraan Sosial Indonesia. Jakarta : Kompas.

Kepaniteraan dan Sekretariat Jenderal Mahkamah Konstitusi. Aktualisasi Masyarakat Hukum Adat: Perspektif Hukum dan Keadilan Terkait dengan Status Masyarakat Hukum Adat dan Hak-Hak Konstitusionalnya. Pusat Penelitian dan Pengkajian Perkara, Pengelolaan Teknologi Informasi dan Komunikasi Kepaniteraan dan Sekretariat Jenderal Mahkamah Konstitusi RI

Menski, Werner. Comparative Law in Global Context: The Legal Sistem of Asia and Africa, Second Edition. UK :Cambridge University Press.

Peter Cane. (2002). Responsibility In Law and Morality. Oxford : Portland Oregon.

Rasuanto, Bur. (2005). Keadilan Sosial : Pandangan Deontologis Rawls Dan Habermas (Dua Teori Filsafat Politik Modern). Jakarta : Penerbit P.T. Gramedia Pustaka Utama.

Ronald Dworkin. (1985). A Matter of Principle. Cambridge : Harvard University Press. (1986). Law's Empire. Cambridge : The Belknap Press.

(2000). The Sovereign Virtue : The Theory and Practice of Equality. Harvard University Press.

(2005). Freedom's Law : The Moral Reading Of American Constitution. London: Oxford University Press.

(2011). Justice for Hedgehogs. Cambridge : The Belknap Press.

(2013). Taking Right Seriously. London : Bloomsbury Academic.

Satjipro Rahardjo. (2009). Hukum Progresif : Sebuah Sintesa Hukum Indoensia. Yogyakarta : Genta Publishing.

Satjipto Rahardjo. (2007). Mendudukkan Undang-Undang Dasar : Suatu Pembahasan

Dari Optik Ilmu Hukum Umum. Semarang : Badan Penerbit Universitas Diponegoro.

Satjipto Rahardjo. (2007). Mendudukkan Undang-Undang Dasar : Suatu Pembahasan

Dari Optik Ilmu Hukum Umum. Semarang : Badan Penerbit Universitas Diponegoro. 
Wojciech Sadurski. (1985). Giving Desert Its Due : Social Justice and Legal Theory. Holland : D. Reidel Publishing Company.

Yance Arizona (ed). (2010). Antara Teks dan Konteks : Dinamika Pengakuan Hukum Terhadap Hak Masyarakat Adat Atas Sumber Daya Alam di Indonesia. Jakarta: HuMA.

\section{Journals:}

Bambang Winarso. Dinamika Pola Penguasaan Lahan Sawah di Wilayah Pedesaan di Indonesia. Jurnal Penelitian Pertanian Terapan, Volume 12, Number 3, 2017.

Emilianus Yakob Sese Tolo. "Akumulasi Melalu Perampasan dan Kemiskinan di Flores." Masyarakat: Jurnal Sosiologi, Volume 21, Number 2, 2016.

Fatimah. Reforma Agraria Dalam Konteks Peningkatan Akses Kaum Tani Miskin Terhadap Penguasaan Tanah di Indonesia. Jurnal Hukum Samudera Keadilan, Vol. 10, No. 2 Juli-Desember 2015.

Husen Alting. Konflik Penguasaan Tanah di Maluku Utara : Rakyat Versus Penguasa dan Pengusaha. Jurnal Dinamika Hukum Volume 13, Number 2 Mei 2013.

Jerzy Wroblewski. Legal Reasoning In Legal Interpretation. Logique et Analyse, Nouvelle Série, Volume 12, Number 45, Maret 1969.

Julius Sembiring. Hak Menguasai Negara Atas Sumber Daya Agraria. Bhumi Volume 2 Number 2 November 2016.

Lilis Mulyani. Pengelolaan Sumber Daya Alam Di Mata Mahkamah Konstitusi : Analitis Kritis Atas Putusan Mahkamah Konstitusi tentang Sumber Daya Alam. Jurnal Masyarakat \& Budaya, Volume 10 No. 2 Tahun 2008.

M. Yazid Fathoni. Konsep Keadilan Dalam Pengelolaan Dan Pemanfaatan Sumber Daya Alam Menurut Undang-Undang Pokok Agraria Tahun 1960. Jurnal IUS, Vol. 1 Nomor 1, April 2013.

Manko, R. T. Ideology and Legal Interpretation: Some Theoretical Considerations. In Constitutional Values in Contemporary Legal Space, Volume I, 2016.

Michael Kirby. Statutory Interpretation : The Meaning of Meaning. Melbourne University Law Review, Volume 35.

Muhammad Ilham Arisaputra. Access Reform Dalam Kerangka Reforma Agraria Untuk Mewujudkan Keadilan Sosial. Perspektif, Vol. XXI No. 2 Tahun 2016 Edisi Mei.

Nurma Khusna Khanifa. Konstitusi Agraria Upaya Reforma Agraria Melalui Program LARASITA Pensertifikatan Hak Milik Atas Tanah. Syariati, Volume II No. 2, November 2016

O.K. Saidin. Nasionalisasi Perusahaan-Perusahaan Milik Belanda Atas Tanah Konsesi Kesultanan Deli (Studi Awal Hilangnya Hak-Hak Atas Sumber Daya Alam Masyarakat Adat). Yustisia, Volume 4. No. 1, Januari - April 2015.

Peter A. Corning. The Fair Society : It's Time To Rewrite Social Contract. Seattle Journal for Social Justice, Vol. 11, Issue I, 2012. 
Radbruch, Gustav.Statutory Lawlessness and Supra-Statutory Law (1946), diterjemahkan oleh Bonnie Litschewski Paulson dan Stanley L. Paulson. Oxford Journal of Legal Studies, Vol. 26, No. 1 (2006).

Sukirno. Kebijakan Afirmatif Pengakuan dan Perlindungan Hak-Hak Masyarakat Hukum Adat. Jurnal Masalah-Masalah Hukum Jilid 44 No. 3, Juli 2015.

Suradi. Pembangunan Manusia, Kemiskinan dan Kesejahteraan Sosial : Kajian Tentang Kebijakan Pembangunan Kesejahteraan Sosial di Nusa Tenggara Barat. Jurnal Penelitian dan Pengembangan Kesejahteraan Sosial, Vol. 12, No. 03, 2007.

Vel, J.A.C. \& Makambombu, S., (2010) 'Access to Agrarian Justice in Sumba, Eastern Indonesia', Law, Social Justice E Global Development Journal (LGD), Vol.1, 2010.

William N Eskridge. Public Values In Statutory Interpretation. University of Pennsylvania Law Review, Vol. 137, No. 4, April 1989.

Yance Arizona. Perkembangan Konstitusionalitas Penguasaan Negara Atas Sumber Daya Alam Dalam Putusan Mahkamah Konstitusi. Jurnal Konstitusi, Vol. 8, No. 3, Juni 2011.

Yanis Maladi. Dominasi Negara Sebagai Sumber Konflik Agraria di Indonesia. Jurnal Masalah-Masalah Hukum, Jilid 41, No. 3, Juli 2012.

\section{Executive Report, Working Paper}

Ashwini Deshpande. 2006. Affirmative Action In India And The United States. World Development Report.

Imelda Saragih et.al. Kertas Posisi Percepatan Penyelesaian Konflik Agraria dalam Kerangka Reforma Agraria dengan Berbasis Hak Asasi Manusia. Jakarta : Komisi Nasional Hak Asasi Manusia.

Joyo Winoto. Reforma Agraria : Mandat Politik, Konstitusi dan Hukum dalam Rangka Mewujudkan Keadilan dan Kesejahteraan Rakyat. Pidato Disampaikan dalam Rapat Senat Terbuka Universitas Gajah Mada, 22 November 2007.

Laporan Akhir Tahun 2012 Konsorsium Pembaruan Agraria. “Terkuburnya Keadilan Agraria Bagi Rakyat Melalui Reforma Agraria"

Sri Edi Swasono. 2007. Indonesia is Not for Sale: Sistem Ekonomi Nasional Untuk Sebesar-Besar Kemakmuran Rakyat. Makalah Rapat Kerja Terbatas Kelompok Kerja Khusus Dewan Ketahanan Nasional 20-21 November 2007.

\section{Website}

Paine, Thomas. 1999. Agrarian Justice, Digital edition. Diakses dari http://piketty.pse. ens.fr/files/Paine1795.pdf tanggal 9 Desember 2018 Pukul 11. 04 WIB.

Vivi Alatas et.al. 2016. Ketimpangan Yang Semakin Lebar. The World Bank dan Australian Aid. diakses dari http://pubdocs.worldbank.org/en/9864/ Indonesias-RisingDivide-Bahasa-Indonesia.pdf. 